\title{
An Investigation of L1 Influence on Japanese and Chinese Native Speakers' Use of English Tense Forms
}

\author{
Rose-Ellen Kesselly \\ The University of Queensland
}

\begin{abstract}
This study investigates L1 influence on Japanese and Chinese native speakers' use of English simple present and simple past tense. A comparative analysis of English simple present and simple past tense and corresponding forms in Japanese and Chinese was conducted through literature review enabling the identification and analysis of L1 influences in Japanese-English and Chinese-English Interlangauges (JIL and CIL).

Samples of JIL and CIL were obtained through guided conversation with four Japanese native speakers and four Chinese native speakers. Tendencies in the use of simple present tense and simple past tense forms produced in the JIL and CIL samples were identified, and through comparison of Interlanguage tendencies to L1 forms, the nature of L1 influence was analysed. It was found that most of the identified tendencies shared features of the speakers' L1 forms. These findings supported the hypothesis that tense and aspect forms produced in JIL and CIL are characterised by features of the speakers' respective L1 forms. Due to limitations on the extent of this study more extensive research is required to confirm these findings.
\end{abstract}

\section{Keywords}

L1 influence, tense, Japanese, Chinese, English

\section{INTRODUCTION}

This study will investigate how Japanese and Chinese native speakers' usage and understanding of English simple present and simple past tense is affected by their respective L1 (first language) knowledge. This will be achieved by firstly conducting a comparative analysis of English tense forms and corresponding Japanese and Chinese forms, and then applying these findings to Japanese and Chinese native speakers' 
English-Interlanguage ${ }^{1}$ (JIL and CIL) samples.

\subsection{Hypothesis}

Simple present and simple past tense forms produced in JIL and CIL are characterised by features of the speakers' respective L1 forms. This is observable through the application of comparative analysis findings to JIL and CIL samples.

\subsection{Objectives}

The three objectives of this study are as follows:

1- To create a comparative analysis of English simple present and simple past tense and corresponding forms in Japanese and Chinese by drawing together the findings of a number of linguistic studies.

2- To identify tendencies in JIL and CIL use of tense forms and to observe how these JIL and CIL tendencies compare to each other and to target English.

3- To analyse the extent and nature of L1 influence in the observed JIL and CIL tendencies, utilising the information provided by the comparative analysis of English, Japanese and Chinese forms.

\subsection{Rationale}

The acquisition of tense is considered by many to be one of the most important and most difficult parts of language learning (Shirai \& Kuruno 1998; Lee 2001). This study attempts to facilitate the teaching of English tense forms to Japanese and Chinese native speakers.

Prior linguistic knowledge both facilitates and inhibits second language acquisition (Bley-Vroman 1989:52). It is facilitating in that the learner is already tacitly aware of a number of language universals. This makes features of an L2 that

1 The term 'Interlanguage' refers to 'a learner's attempted production of a TL (target language) norm' (Selinker 1972:214). Interlanguages typically contain features of both the learner's L1 and the target language. See section 2.1. 
.

are universal to all languages relatively easy to understand and accept. However, prior linguistic knowledge can also have an inhibiting effect on the acquisition of an L2. This occurs when a learner over generalises and assumes that certain features of his/her L1 are language universals, when in fact they are specific to the learner's L1 (Bley-Vroman 1989).

I hope that by making differences between English tense forms and corresponding L1 forms explicit, and by creating an awareness of how these differences affect the use of tense forms in JIL and CIL, this study will benefit teachers of Japanese and Chinese native speakers. If teachers have an understanding of their students' L1 and the way that L1 grammar affects learners' understanding of L2 grammar, then they are able to effectively identify the root of grammatical difficulties. This enables teachers to address these difficulties with appropriate explanations and teaching strategies.

I hope that this study will promote further research into L1 influence and teaching methods that specifically address difficulties caused by L1 influence.

\section{LITERATURE REVIEW}

\subsection{Approaches Studying L1 Influence in SLA}

\section{Contrastive Analysis:}

Contrastive Analysis was a method of predicting L1 interference in SLA, popular from 1945 to 1965. By conducting detailed comparisons of L1 grammar and target language grammar, Contrastive Analysis studies attempted to predict errors and areas of difficulty in L2 acquisition. Lado (1957:1) stated, 'In the comparison between native and foreign language lies the key to ease or difficulty in foreign language learning.'

In the 1960s Contrastive Analysis became unpopular as it was found that predictions were not always consistent with learners' actual performance. Not all differences between an L1 and a target language resulted in significant difficulty in acquisition, and not all difficulties in L2 acquisition were the result of L1 and target language differences (Odlin 1985; Ellis 2005). It is now known that L1 influences interact with a number of other factors, such as, complexity of L2 structures, universal tendencies, and instructional influences. This is why Contrastive Analysis studies failed in their attempt to predict hierarchies of difficulty in L2 acquisition. 
Despite the shortcomings of Contrastive Analyses, both Fries (1945) and Lado (1957) rightly observed that many learner difficulties appear to be caused by the influence of the learners' L1. Fries (1945) indicated that as a result of L1 influences, learners from different L1 backgrounds often face different difficulties when acquiring the same L2. A number of studies conducted at that time confirmed this assumption, and verified that 'many linguistic distortions heard among bilinguals correspond to describable differences in the languages involved,' (Lado 1957:1). This proposition is still valid and relevant to current research. Fries, Lado and other Contrastive Analysis linguists were also justified in their conviction that such a phenomenon cannot be properly analysed or understood without an understanding of the similarities and the differences between the learner's L1 and the target language.

\section{Error Analysis:}

Contrastive Analysis was followed by Error Analysis, an analytical rather than predictive approach to studying difficulties in L2 acquisition. Error Analysis identified errors in learners' productions rather than trying to predict them. Once errors were identified, they were then analysed in terms of the kind of error and their likely cause (L1 influence or other).

Corder (1981) emphasised that errors were significant to researchers in that they provided evidence as to the nature of second language acquisition. It was found that errors were not random, but systematic, and the kinds of errors made by learners represented developmental stages of acquisition.

Despite the contribution that Error Analysis made to the field of second language acquisition, this approach was not without limitations. Error Analysis looked only at errors, a restricted portion of learner production. This caused problems such as avoidance to be overlooked. Error Analysis failed to look at areas where learners were competent and therefore failed to see the whole picture.

\section{Interlanguage and Integrative Studies:}

Interlanguage was a term coined by Selinker (1972) that developed on Corder's notion of systematicity and developmental stages in learner errors. Rather than looking only at 'errors', however, the term 'Interlanguage' covers both non target-like and targetlike production of an L2. Selinker (1972:214) described a learner's Interlanguage as 'a separate linguistic system based on the observable output which results from a learner's 
.

attempted production of a TL (Target Language) norm'. The term 'Interlanguage' has allowed linguists to view learner produced language from a new perspective, as languages in their own right with their own systematic grammars.

In order to identify L1 influence in the Interlanguage being examined, many Interlanguage studies adopted methods similar to Contrastive Analysis. Yip's (1995) study of Chinese-English Interlanguage (CIL), for example, examined and compared the 'topic prominence' of Chinese and the 'subject prominence' of English, and then analysed a number of CIL tendencies that resulted from the influence of Chinese topic prominence. Chan's (2004) study of syntactic transfer in CIL also comparatively analysed five syntactic structures in English and in Chinese, then identified discrepancies between CIL and target English that were likely to be the result of L1 influence.

Waibel (2005) noted the importance of comparing the Interlanguages of two L1 groups when investigating L1 influence. German and Italian English-Interlanguages were compared to English to determine non target-like productions. Comparisons of the two varieties of English-Interlanguages to each other, determined whether deviations from target English were likely to be the result of universal tendencies, or whether they were specific to that particular L1 group.

All three studies above (Yip 1995, Chan 2004, and Waibel 2005) found that L1 did have a significant influence on English-Interlanguage tendencies. These three studies proved to be effective as they combined the strengths and avoided the weaknesses of several methods. They comparatively analysed L1 and TL, but took an analytical rather than predictive approach to identifying and understanding areas of L1 influence in learners' production of the L2. They took a holistic approach, examining not only non target-like structures, but also the Interlanguages as whole languages.

\section{The Approach of this Study:}

This study will take an integrative approach similar to that of Yip (1995), Chan (2004), and Waibel (2005). Following Contrastive Analysis methods I will develop a structured comparative analysis of English, Japanese, and Chinese forms (Section 2.3). However, in contrast to the Contrastive Analysis approach, I will not attempt to predict errors or areas of difficulty. I will simply use these comparisons as tools in the analysis of Interlanguage samples. Using the Interlanguage approach, I will not only look at 'errors', but will identify Interlanguage patterns through observation of both target-like and non target-like production of tense forms in JIL and CIL. 


\subsection{Tense}

The function of tense is to temporally locate a situation in relation to a deictic centre (or temporal anchoring point) which is usually the moment of speech (Reichenbach 1947; Comrie 1976 and 1985; Smith 1991; Olsen 1997; Xiao \& McEnery 2004). Reichenbach (1947) used three time points to describe the temporal relations expressed by tenses: the time of speech (ST); the time of the event (ET); and the time of reference (RT). Using these three time points, simple tenses can be described by the following formulas (a comma indicates temporal simultaneity, and a dash indicates that what is on the left is temporally located prior what is on the right):

\section{ET,RT_ST (simple past) \\ ET,RT,ST (simple present) \\ ST_ET,RT (simple future)}

The above formulas proposed by Reichenbach work well for tenses (such as English tenses) that invariably take ST as their deictic centre. These are called 'absolute tenses' (Comrie 1985). However, in some languages, such as Japanese, tenses can take some other point in time as their deictic centre. These are called 'relative tenses' (Comrie 1985). To make formulas universal to both tense types, recent studies, such as Olsen (1997), use 'C' rather than ST to represent the deictic centre.

Another issue regarding tense, raised by Comrie (1985) is whether a tense asserts the temporal location of all, or only part, of a situation. While tense temporally locates a situation, it does not necessarily assert whether or not the situation extends beyond or before that temporal location (Comrie 1985). The following example demonstrates that it is possible for an ET to extend beyond the temporal location asserted by tense.

Mary knew that Susan was a vegetarian. (That's why she didn't offer her a sausage at the BBQ yesterday).

There is no indication in the sentence that Mary's knowledge of Susan being a vegetarian no longer continues. It is also possible for an RT to extend beyond the temporal location asserted by a tense. For example, 'I baked a cake today.'

In summary, tense temporally locates situations in relation to a deictic center (C), which may be ST or some other point in time. Tenses locate at least part of the ET and RT, prior to, simultaneous with, or after C. If one understands that tense only 
.

necessarily asserts the temporal location of part of the ET and part of the RT, then the following formulas can be used: past (ET,RT_C); present (ET,RT,C); and future (C_ET,RT).

\subsection{Aspect}

In many languages, including English and Japanese, the tense category overlaps with the aspect category, as both tense and aspect describe temporality in some way. Some languages, such as Chinese, do not have a tense category, but only an aspect category. For these reasons it is necessary to discuss aspect in this study.

Unlike tense, aspect is not concerned with the temporal location of a situation, it does not relate a situation to a deictic centre (Comrie 1976; Smith 1991; Olsen 1997). Aspect is concerned with the internal temporal structure of a situation, and how much, or what part, of that structure is visible in a sentence (Comrie 1976; Smith 1991). Smith (1991) compares the function of aspect to that of a camera lens that can focus on all or part of the situation. Throughout the literature the most commonly quoted definition of aspect is 'different ways of viewing the internal temporal constituency of a situation' (Holt 1943, translated by Comrie 1976:3).

There are two basic aspectual viewpoints: perfective and imperfective (Comrie 1976, Smith 1991, Olsen 1997; Shang 2004; Xiao \& McEnery 2004). Perfectives, according to Comrie (1976:3), present 'the totality of the situation referred to ... without any reference to its internal temporal constituency: the whole of the situation is presented as a single unanalysable whole, with beginning, middle and end rolled into one.' Comrie describes Imperfectives on the other hand as viewpoints that 'make explicit reference to the internal temporal constituency of the situation' (Comrie 1976:4). Smith (1991), following her camera lens analogy, emphasizes that both end points (start and finish) of a situation must be visible in a perfective viewpoint, and that only an internal phase, excluding endpoints must be visible in an imperfective viewpoint.

\subsection{Situation Types}

As both tense and aspect forms interact differently with different situation types, it is necessary to have an understanding of situation types and their inherent temporal features. This is referred to in the literature as 'situation aspect' (Smith 1991; Xiao \& McEnery 2004) or 'lexical aspect' (Olsen 1997).

Situations can be classified into different types according to their combinations of certain inherent temporal features. Vendler (1967) proposed three binary features 
(+/- Dynamic, +/- Telic, and +/- Durative) and identified four situation types (States, Activities, Accomplishments, and Achievements), each with a unique combination of the three features. This system, summarised below, has since been adopted by many modern linguists (for example: Comrie 1976; Smith 1991; Olsen 1997; Xiao and McEnery 2004).

Situation types and their inherent temporal feature combinations can be summarised in the following table:

Table 1: Temporal Features of Basic Situation Types

\begin{tabular}{|l|c|c|c|}
\hline & Dynamic & Telic & Durative \\
\hline State & - & - & + \\
\hline Activity & + & - & + \\
\hline Accomplishment & + & + & + \\
\hline Achievement & + & + & - \\
\hline
\end{tabular}

\section{Dynamic:}

Dynamic situations are situations that involve change and require energy. Since States are unchanging and require no energy they are said to lack the feature of Dynamicity. All other situation types are + Dynamic.

John is playing tennis. (+Dynamic : Activity)

John baked a cake. (+Dynamic : Accomplishment)

John is tall. (-Dynamic: State)

Telic:

Telic situations are those that have a 'final spatial endpoint', (Xiao \& McEnery 2004:46). If uninterrupted, Telic situations naturally come to completion, without the need for arbitrary termination. 
John ate a sandwich. (+Telic: Accomplishment)

Mary arrived at school. (+Telic : Achievement)

The -Telic feature is used to distinguish Activities from other Dynamic Situations. Situations that lack telicity (States and Activities) could continue indefinitely as they have no natural final end point.

John has a car. (-Telic : State)

John studies English. (-Telic : Activity)

\section{Durative:}

Durative situations are situations that are lasting or take time to reach completion. The Durative feature is used to separate the two + Telic situation types, Accomplishments and Achievements. Accomplishments are +Durative, as they indicate a process leading up to the final spatial endpoint. Achievements on the other hand, are instantaneous. They are perceived as taking up no space in time at all as the initial endpoint occurs at exactly the same time as the final endpoint.

Mary built a house. (+Durative : Accomplishment)

I watched a movie. (+Durative : Accomplishment)

John finished the cake. (-Durative : Achievement)

Mary decided. (-Durative : Achievement)

\section{Derived Situation Types:}

In addition to these four basic situation types, there are also a number of derived situation types.

Basic States and Activities are not bounded, as they are atelic and lack both spatial and temporal endpoints. However, Xiao \& McEnery (2004) observe that temporal endpoints can be provided in the sentence, by delimiting devices such as 'for three hours'. This makes the situations temporally bounded, producing derived situation types, which are referred to by Xiao \& McEnery as 'bounded States', and 'bounded Activities'. Examples of temporally bounded States and Activities are provided below:

John lived in London for 20 years. (bounded State) 
Mary danced from $3 \mathrm{pm}$ to $5 \mathrm{pm}$. (bounded Activity)

When basic Dynamic situation types; Activities, Accomplishments and Achievements refer to situations that are habitual, they become State-like. According to Comrie (1985) a sentence expressing habituality assigns 'a certain property' to the subject of the sentence. Rather than a single Dynamic event, a habitual sentence describes a 'characteristic situation' that holds indefinitely, like a State (Comrie 1985:39). The original features of Telicity and Dynamicity are lost, producing a derived situation type. In this article I will follow Smith's (1991) terminology, and refer to this derived situation type as 'Habitual Stative'. Some examples of Habitual Statives in English are provided below:

I study at university.

I cook dinner every night.

\subsection{Universal Tendencies in the Acquisition Tense and Aspect forms}

Although this study is primarily concerned with Interlanguage tendencies that are specific to learners of particular L1 backgrounds, an understanding of universal tendencies is also important. If universal influences are understood and taken into account, a more thorough and accurate analysis of L1 influences is made possible.

A theory known as 'the Aspect Hypothesis' or the 'Lexical Aspect Effect' emerged in the late 1980s (Robison 1990; Shirai \& Kuruno 1998; Li \& Shirai 2000; Collins 2004). This theory suggests that learners from all L1 backgrounds make certain non target-like associations between $\mathrm{L} 2$ tense and aspect forms, and situation types. Learners first use L2 tense and aspect forms to redundantly mark the situation type of the sentence, rather than to mark tense or viewpoint aspect. This represents a universal developmental sequence where past tense forms and perfective aspect forms are associated with telic situation types, namely Accomplishments and Achievements, imperfective aspect forms are associated with Activities and present tense forms are associated with States.

In the analysis of JIL and CIL use of tense and aspect forms (Chapter 4) this article will compare identified tendencies to the characteristics of tense and aspect forms in Japanese and Chinese, while also taking the assertions of the Aspect Hypothesis into account. In this way, tendencies will be able to be identified as either resulting from L1 influence, or as resulting from universal influences. 
.

\subsection{Comparative Analysis of English, Japanese, and Chinese forms}

\section{English Simple Present Tense:}

The function of English simple present tense is to temporally locate situations, at least partially, simultaneous with Speech Time (Comrie 1985). Any Reference Time in the sentence must also be, at least partially, simultaneous with Speech Time. English present tense is not compatible with a past Reference Time, even if the Event Time of the situation spans both past and present time. This follows the formula for absolute present tense described in section 2.2: ET,RT, C(ST). The interaction of simple present tense with situation types will be discussed below.

States with the simple present tense may extend beyond Speech Time indefinitely into both past and future time. They cannot, however, be used with past or future Reference Times, or contexts. The incompatibility of simple present States with past and future Reference Times is demonstrated in the following examples:

I am sick at the moment. (present tense State with present RT)

${ }^{\star}$ I am sick yesterday. (present tense State with a past RT)

${ }^{\star} \mathrm{I}$ am sick tomorrow. (present tense State with a future RT)

Leech (1971) refers to the ability of present tense to describe States that extend beyond Speech Time as the 'unrestrictive use' of the simple present. He states that the present tense when used with States 'places no limitation on the extension of the State into past and future time' (Leech 1971:1).

Except in rare circumstances, English simple present does not occur with Dynamic situation types. When an ordinarily Dynamic predicate takes simple present tense, it is presented as a Habitual Stative rather than a true Dynamic situation (Biber et al 1999). See the example below:

I wash the dishes.

I wake up at 6am.

As with States, Habitual Statives with simple present tense are not restricted to Speech Time. They can extend indefinitely into the past or the future, but are not compatible with past Reference Times.

In summary, English simple present tense can be used with States and Habitual 
Statives, described with present Reference Times or in present contexts, temporally locating them partially in the present without restricting their extension into past and future time.

\section{English Simple Past Tense:}

The function of English simple past tense is to temporally locate situations, at least partially, prior to Speech Time. This follows the formula for absolute past tense described in section 2.2: ET,RT_C(ST). With Dynamic situations, English Simple Past also has an aspectual function of presenting situations perfectively (Comrie 1976; Smith 1991). The interaction of simple past tense with situation types will be examined below.

With States and Habitual Statives, simple past tense behaves in a similar way to the simple present tense. Simple past tense does not restrict States and Habitual Statives to a past time. Regardless of whether or not a past State or Habitual Stative extends into the present time, past tense must be used if a past Reference Time is given (Comrie 1985). Even if the sentence does not actually provide a past Reference Time, in the context of a past situation, continuing States are usually described with past tense. The examples below demonstrate that past tense is often used for States and Habitual Statives that are still continuing.

I loved drawing when I was a child and I still do.

(continuing State- past RT)

I knew the answer was ' 6 ', but I didn't get time to write it down.

(continuing State- past context)

I always ate bananas when I was little and I still do.

(Continuing Habitual - past RT)

Dynamic situations on the other hand are presented perfectively with English simple past tense and cannot extend beyond past time. In sentences such as, 'I built a house', the situation is viewed as complete, both initial and final endpoints are visible, and the entire event is located prior to Speech Time (Smith 1991; Comrie 1976). As demonstrated below, the addition of information contradicting the completion of a Telic situation with past tense creates an anomalous sentence (Smith 1991).

${ }^{*}$ I built a house but I didn’t finish building it.

All Dynamic situations with simple past are either completed or terminated prior to Speech Time (Smith 1991). Accomplishments and Achievements are completed, in that 
.

they have reached their natural final spatial endpoints, and Activities are terminated, in that they have reached arbitrary final temporal endpoints.

In summary, the Event Time of Dynamic situations with English simple past tense cannot extend beyond Speech Time. The Event Time of States and Habitual Statives with simple past, however, is not restricted to past time and may extend into present and future time, as long as the Reference Time or context is located in the past.

\section{Japanese Relative Tense:}

Japanese tense is said to be relative. As in English, tenses of main clauses in Japanese temporally locate the Event Time of the situation in relation to Speech Time. However, the tense of a subordinate clause in Japanese, temporally locates the subordinate clause situation, not in relation to Speech Time, but in relation to the Event Time of the main clause situation (Kunihiro 1989; Teramura 1982; Ogihara 1999; Wada 2001).

\section{Japanese 'ru':}

Japanese $r u$ has overlapping tense and aspect functions. As an aspect, $r u$ views a situation at its incomplete or unrealised phase (Teramura 1982; Kunihiro 1989; Soga 1983). As a tense, $r u$ temporally locates situations in the relative 'non-past' (Soga 1983), which is either relative present (C,RT,ET) or relative future (C_RT,ET ) (Teramura 1982; Soga 1983; Yoshimoto 1998; Ogihara 1999).

With States, $r u$ has only a tense, not an aspect function (Teramura 1982; Yoshimoto 1998; Soga 1983). $R u$ temporally locates States, at least partially, in the relative present. Like States with simple present tense in English, States with $r u$ can extend indefinitely into past and future time, but cannot occur with a past Reference Time. For this reason the following example and its literal English translation are both ungrammatical:

*昨日病気だ。( $r u$ with past RT)

(Kinou byouki da.)

*Yesterday I am sick. (simple present with past RT)

Like English simple present, Japanese $r u$ can also be used with Habitual Statives. As with States, $r u$ temporally locates Habitual Statives, at least partially, in the relative 
present and places no restriction on how far they extend into past and future time.

Unlike English simple present, $r u$ often occurs with Dynamic situations. $R u$ presents Dynamic situations as unrealised, temporally locating them in the relative future (Teramura 1982).

In summary, Japanese $r u$ temporally locates Dynamic situations in the relative future and temporally locates States and Habitual Statives, at least partially, in the relative present.

Japanese 'ta':

Japanese $t a$ is primarily a marker of relative past tense, but can also have aspectual functions.

With States ta only has a tense function, namely to locate the State, at least partially, in the past (Teramura 1982; Yoshimoto 1998). Like English simple past, ta does not assert that a State has been terminated (Kindaichi 1955 cited in Teramura 1982). Ta can be used to refer to a State that is still continuing if it is referred to with a past Reference Time or in a past context. Yoshimoto (1998:52) gives the following example and English translation. The Japanese sentence takes $t a$, just as the English sentence takes simple past, even though the State described was most likely still true at Speech Time:

昨日とまった旅館には庭に大きな松の木があつた。

(Kinō tomat-ta ryokan ni wa niwa ni ōkina matsu no ki ga at-ta.)

(In the garden of the hotel we stayed at yesterday, there was a tall pine tree.)

Like English simple past, ta can also be used to describe past Habitual Statives.

Dynamic situations with ta, like Dynamic situations with English simple past, are presented perfectively. Both end points are visible and located in the past. The same test that was applied to Telic situations with English simple past can also be applied to Telic situations with Japanese ta. As shown in the following anomalous sentence, a Telic situation with Japanese ta cannot be followed by an assertion that the situation was not completed:

*ケーキを作ったが終わらなかつた。

(Ke-ki wo tsukutta ga owaranakatta.)

${ }^{\star}$ I made a cake but I didn't finish. 
.

Chinese 'le':

As Chinese does not have tense forms, here I will examine a Chinese aspect marker, post-verbal $l e$. Though primarily a perfective aspect, $l e$ can also imply relative past tense and is therefore often associated with past tense.

The essential characteristic of $l e$ is that it asserts actualisation, and focuses on the totality of a situation (Xiao \& McEnery 2004). Le, like all typical perfective viewpoints, spans both the initial and final end point of a situation (Smith 1991). Xiao \& McEnery (2004) observe that the following Telic situation marked with le followed by an assertion that the situation was not completed creates an anomalous sentence in Chinese.

*我昨天写了给张三的新可是没写完。

( ${ }^{\star}$ Wo zuotian xie-le gei Zhangsan de xin, keshi mei xie-wan.)

( ${ }^{\star}$ I wrote a letter to Zhangsan yesterday but I didn’t finish writing it.)

In this way, le is similar to both Japanese ta and English simple past. All three of these forms present Dynamic situations perfectively. Telic situations are invariably completed, and Activities are invariably terminated with English simple past, Japanese $t a$, and Chinese le.

However, Chinese le differs from Japanese ta and English simple past in its presentation of States. In English and Japanese, States are obligatorily tensed. English past tense and Japanese ta have a purely tense function with States, asserting partial past location, with no indication of whether the situations are continuing or terminated. Chinese le rarely occurs with States. Smith (1991) claimed that $l e$ only occurs with nonstative situations. Xiao and McEnery's (2004) corpus based study found that le does on rare occasions occur with States. Xiao and McEnery (2004:107) attribute the low occurrence of $l e$ with States to the fact that States are 'open ended' and 'may hold for an indefinite interval. Their data showed that when le does occur with States, these States are temporally bounded and are presented as having reached their final temporal endpoint.

In summary, Chinese $l e$ is similar to English simple past and Japanese $t a$ in that it presents dynamic situations as being completed or terminated. However, Chinese le differs to English simple past and Japanese $r u$, in that it rarely occurs with States and does not occur with unbounded States. 


\section{METHOD}

The Interlanguage samples used for analysis in this study came from eight participants' spontaneous oral production in guided conversations. I chose to use spontaneous production data rather than prompted production data, obtained through the use of elicitation tasks, so that participants' Interlanguages could be observed in their natural un-directed state.

In two separate groups (a group of four Japanese native speakers and a group of four Chinese native speakers) participants were guided in informal English conversation. These conversations were tape recorded, for approximately 30 minutes, and later transcribed in order to create the JIL and CIL samples to be used as data for observation and analysis in this study. The eight recruited participants were all advanced adult English students aged between 24 and 28. All eight participants had studied English at high school in their home country and at English language schools in Brisbane.

For both groups of participants the topic of conversation was guided to ensure that participants were provided with opportunities to produce each English tense and aspect form. Participants were asked questions regarding past experiences and lifestyle in their home countries as well as past experiences in Australia, inviting the use of simple past tense. They were also asked about their present situation, inviting the use of simple present tense.

In order to balance the two samples it was necessary to omit some sections of the recorded conversations. To enable comparisons of frequencies of tense forms in JIL and CIL the transcribed conversations were cut so that both Interlanguage samples contained approximately the same number of clauses containing simple present or simple past tense.

Target-like and non target-like uses of Simple Present tense and Simple Past tense, along with the situation types that they were used with, were identified, counted and tabulated for each sample.

Using both figures from Tables 2 and 3 and direct observations of the samples, tendencies in the uses of forms were identified. In contrast to Error Analysis methods (discussed in Section 2.1) target-like uses were also included in the analysis. It was necessary to examine the contexts of target-like uses and compare them to the contexts of non target-like uses. In this way the Interlanguage patterns of use could be clearly identified. Differences between JIL and CIL tendencies were examined, and both JIL and CIL tendencies were compared to target English usage. 
Evidence of L1 influence was analysed through comparison of the identified Interlanguage tendencies to the characteristics of L1 forms. Correlations were identified, and from this the extent and nature of L1 influence was ascertained. Where the observed tendencies did not appear to have a connection to L1 influence, the patterns of usage were compared to universal tendencies as asserted by the Aspect Hypothesis.

\section{DATA AND ANALYSIS}

Table 2 and Table 3 show the distribution of simple present and simple past tense forms across situation types, produced in the JIL and CIL samples. The number on the top left of each cell represents the total number of forms produced with each situation type. The number in the second line of each cell, marked with an asterisk, represents the number of these productions that are non target-like (simple past used rather than simple present, and vice versa). 
Table 2: Distribution of Simple Present and Past across Situation Types in JIL (from a total of 306 clauses)

\begin{tabular}{|c|c|c|c|c|}
\hline \multicolumn{2}{|l|}{ JIL } & $\begin{array}{l}\text { Simple } \\
\text { Present }\end{array}$ & $\begin{array}{l}\text { Simple } \\
\text { Past }\end{array}$ & Total \\
\hline \multicolumn{2}{|l|}{ States } & $\begin{array}{l}161(53 \%) \\
37^{\star}\end{array}$ & $\begin{array}{l}53(17 \%) \\
1^{\star}\end{array}$ & $\begin{array}{l}214(70 \%) \\
38^{\star}\end{array}$ \\
\hline \multirow{3}{*}{ อ. } & Activities & $4(1 \%)$ & $7(2 \%)$ & $11(4 \%)$ \\
\hline & Accomplishments & - & $12(4 \%)$ & $12(4 \%)$ \\
\hline & Achievements & $\begin{array}{l}1(0 \%) \\
1^{*}\end{array}$ & $\begin{array}{l}13(4 \%) \\
1^{*}\end{array}$ & $\begin{array}{l}14(5 \%) \\
2^{\star}\end{array}$ \\
\hline \multicolumn{2}{|c|}{ Habitual Statives } & $\begin{array}{l}42(14 \%) \\
7^{\star}\end{array}$ & $\begin{array}{l}13(4 \%) \\
1^{\star}\end{array}$ & $\begin{array}{l}55(18 \%) \\
8^{\star}\end{array}$ \\
\hline \multicolumn{2}{|l|}{ Total } & $\begin{array}{l}208(68 \%) \\
44^{*}\end{array}$ & $\begin{array}{l}98(32 \%) \\
3^{*}\end{array}$ & $\begin{array}{l}306(100 \%) \\
47^{\star}\end{array}$ \\
\hline
\end{tabular}


New Voices Volume 2

Table 3: Distribution of Simple Present and Past across Situation Types in CIL (from a total of 313 clauses)

\begin{tabular}{|c|c|c|c|c|}
\hline \multicolumn{2}{|l|}{ CIL } & $\begin{array}{l}\text { Simple } \\
\text { Present }\end{array}$ & $\begin{array}{l}\text { Simple } \\
\text { Past }\end{array}$ & Total \\
\hline \multicolumn{2}{|l|}{ States } & $\begin{array}{l}182(58 \%) \\
22^{*}\end{array}$ & $28(9 \%)$ & $\begin{array}{l}210(67 \%) \\
22^{*}\end{array}$ \\
\hline \multirow{3}{*}{ อُ } & Activities & $2(1 \%)$ & $6(2 \%)$ & $8(3 \%)$ \\
\hline & Accomplishments & $\begin{array}{l}2(1 \%) \\
1^{*}\end{array}$ & $15(5 \%)$ & $\begin{array}{l}17(5 \%) \\
1^{*}\end{array}$ \\
\hline & Achievements & $\begin{array}{l}3(1 \%) \\
1^{*}\end{array}$ & $20(6 \%)$ & $\begin{array}{l}23(7 \%) \\
1^{*}\end{array}$ \\
\hline \multicolumn{2}{|c|}{ Habitual Statives } & $\begin{array}{l}50(16 \%) \\
18^{\star}\end{array}$ & $\begin{array}{l}5(2 \%) \\
1^{\star}\end{array}$ & $\begin{array}{l}55(18 \%) \\
19^{*}\end{array}$ \\
\hline \multicolumn{2}{|l|}{ Total } & $\begin{array}{l}239(\%) \\
42^{*}\end{array}$ & $\begin{array}{l}74(\%) \\
1^{\star}\end{array}$ & $\begin{array}{l}313(100 \%) \\
43^{*}\end{array}$ \\
\hline
\end{tabular}

A common problem, found in both JIL and CIL, was non target-like production of the simple present tense, in other words, failure to use past tense in contexts where past tense was either obligatory or preferable. In this section I will identify two tendencies involving this problem. I will firstly examine failure to use past tense with past Habitual Statives. This was common in CIL. The second tendency that will be examined is failure to use past tense with States. This was evident in both JIL and CIL.

\subsection{Failure to use Simple Past Tense with Habitual Statives}

A common problem in CIL was failure to use past tense when describing past habitual behavior. Although this did occasionally occur in the JIL sample, it was much more prominent in the CIL sample. Only four target-like past tense Habitual Statives were produced in the entire CIL sample. This contrasts to the twelve target-like past tense Habitual Statives produced in the JIL sample. In JIL only seven present tense Habitual 
Statives were non target-like. In the CIL sample however, eighteen present tense Habitual Statives were non target-like, as they were actually describing past Habitual Statives.

The extracts below from the CIL sample demonstrate this tendency. [All Habitual Stative verbs are in bold letters. Habitual Statives with Past Tense are in bold italics. Non target-like uses of tense are followed by asterisks]:

1) When I was in China ...um get ${ }^{\star}$ up at also, I think, 8 oclock. Then play computer games until lunch, then have ${ }^{\star}$ lunch, computer games again, and dinner, have ${ }^{\star}$ dinner until... midnight.

2) When I was in university in Beijing ... one of my room mate, he always... everyday he go $^{\star}$ to... he went to the computer room... and wake up ${ }^{\star}$ at about $8 \mathrm{am}$, and $\mathbf{g o}^{\star}$ there.

3) When I was in Taiwan, after the class I always went out for shopping or do* something else. I never stay ${ }^{\star}$ at home or in my school.

The non target-like uses of present tense with Habitual Statives in the extracts above are non target-like, firstly because they occur with past Reference Times (e.g. 'when I was in China'), and secondly because the Habitual Statives being described do not hold at Speech Time.

\section{Analysis of L1 Influence:}

The reluctance of Chinese native speakers to use past tense with Habitual Statives can be explained by the absence of tense marking in Chinese. Although a Chinese native speaker may associate $l e$ with past tense, $l e$ is not a past tense marker but a perfective aspect marker. As discussed in section 2.6, le occurs with situations that are bounded and can be presented as a complete whole. Since Habitual Statives are actions that are continuously repeated over an unspecified length of time and are not bounded by spatial endpoints, they do not occur with le unless temporal endpoints are explicitly provided in the sentence.

In Chinese, verbs expressing habitual behavior are usually unmarked regardless of temporal location. The temporal location can be specified through lexical means. This is the way temporal location for Habitual Statives was indicated in the CIL sample, e.g. 'when I was in China....' 
.

In English and Japanese, however, Habitual Statives are obligatorily tensed according to their temporal location and Reference Time. Japanese ta is used with Habitual Statives to perform the same function as English past tense with Habitual Statives, namely to temporally locate the Habitual Stative in the past. This positive influence from L1 explains why the Japanese participants had less difficulty using past tense with Habitual Statives.

\subsection{Failure to use Simple Past Tense with States}

Another problem, common in both CIL and JIL, was failure to use past tense with States. It can be seen in the following extract from CIL that production of past tense and failure to produce past tense is not random. The speaker correctly used past tense with Dynamic situations, but failed to use past tense with States. [Simple present tense verbs are in bold letters, and simple past verbs are in bold italics. Verbs of Dynamic situations are underlined. Asterisks placed after verbs mark non target-like uses of tense forms]:

4) I just $\underline{h a d}$ the interview yesterday. But I think I can't get the job. I $\underline{\text { didn't }}$ $\underline{\text { do }}$ good job in the interview. Because the question is ${ }^{\star}$ quite complex ... and there are $^{\star}$ two interviewer, and one of the interviewer, his English is ${ }^{\star} \ldots$ his pronunciation is ${ }^{\star}$ blurred, so don't understand ${ }^{\star}$. And the manager asked me to wait for his call. He said he will call me at the end of this week. (CIL)

This pattern was common throughout both the CIL and JIL sample. The figures suggest that this is more of a problem in JIL than in CIL as there were 37 non target-like uses of present tense with States in the JIL sample, and only 22 in the CIL sample. However, there is evidence in the CIL sample of avoidance of past tense with States. While 53 past tense States were produced in the JIL sample, only 28 were produced in the CIL sample.

Examination of the samples revealed further evidence that the use of past tense with States was often avoided in the CIL sample without actually making the sentences ungrammatical. This can be seen in a comparison of the JIL and the CIL responses to the question 'What were your original purposes for coming to Australia?'. Despite the fact that for both groups, past tense and the word 'original' was used in the question, the responses from the two groups were quite different in both content and use of tense. Extracts from the CIL responses are provided below. [States are underlined, Present Tense forms are in bold, and Past Tense forms are in bold italics]:

5) I'm here... I tried to get some experience about Australia. No matter what kind of job I have, I'm just trying to get something, and trying to make some 
friends here, because I know Australia is kind of a multi-cultures. Yeah that's why... That's one of my purpose. And the other one is to travel. That's why I hope I can make a lot of money here. (CIL)

6) In my case, I just want to improve my English. Because in Taiwan good English (inaudible word) you to get a good job. My major is business in Taiwan.

So I think to spend almost one year to study English is good for me. That's my main purpose. (CIL)

7) I came here to further study. Because my ... when I was in university my major was statistics. But if I want to enroll higher university in Taiwan, I cannot... I think I have no chance. Because my score was quite low so that's why I came here, because I $\underline{\text { nnow }}^{\star}$ this university is a good one. (CIL)

8) Ok ah... I came to Australia for... to get, to actually get a certificate and the experience of work. And I want to experience different lifestyle in Australia and make friends with people of other culture. (CIL)

Extracts from the JIL responses are provided below:

9) For me, I was very interested in teaching Japanese. And also I was interested in learning English. Yes, and I hope one day I can use English at work. That's why I came here. (JIL)

10) Actually I came without no purpose. For me living abroad, living in a foreign country for as long as ... not just as a tourist, for me, I felt necessary... (JIL)

11) Actually I'm same with Saori, because when I was in Japan I worked for trading company, and it was very hard work, I have* to get up early and I have* to work late into the night. So it was very very hard, so I wanted to... I wanna ${ }^{*}$ $\ldots$ at that time I $\underline{\text { wanna }}^{\star}$ quit the job... and after that I $\underline{\text { have }}^{\star}$ no idea what to do .... so that's why just I came here. (JIL)

12) My purpose was English. I wanted to go to university, for that I needed to get 5.5 points for IELTS so that' $\underline{\mathbf{s}}$ why.... Yeah that was the purpose I guess, to go to the hospitality course... three month course... I was thinking about that, but my .. my... changed mean time. First I was thinking about hospitality but, but, I wasn't interested in anymore and yeah... I didn't know what to do.... Just study English and yeah. And the end of the one year I felt like I want to live in Australia, I want to get the permanent visa... I don't know why but I felt like that. (JIL) 
While the Japanese group talked about their past situations and their reasons for wanting to come to Australia, using a combination of past and present tense, the Chinese group appeared to talk more about their present goals, using mostly present tense.

In most cases the use of present tense with States, in the CIL responses to this question, was superficially target-like, however, if the present tense forms were replaced with past tense forms most of these utterances would still be target-like. In Extract 6, for example, the use of present tense is actually unnatural in target English, in the context of the participant's circumstances. The speaker revealed later in conversation that he would be leaving Australia in two weeks, after his eleven-month stay. In the knowledge that his stay is almost over, it is unnatural in target English to state the purpose or goals of his stay in present tense.

A notable difference between JIL and CIL in the use of present tense and past tense with States is their frequencies with States that continue at speech time, and States which have terminated prior to Speech Time. In the CIL sample there were no examples of past tense used with States that were clearly continuing at the moment of speech. All four Japanese participants on the other hand, demonstrated the ability to accurately use past tense with both terminated States and States that were continuing at Speech Time. For example, in Extract 9 above, 'I was very interested in teaching Japanese', and 'I was interested in learning English,' there is no indication anywhere in the sample that the speaker is no longer interested in teaching Japanese and learning English. Her use of past tense here is target-like as she is describing the continuing States in reference to a past situation, namely her decision to come to Australia.

JIL and CIL distributions of past tense across States that were terminated, possibly continuing, and continuing are shown in Table 4 below: 
Table 4: Distribution of JIL and CIL

Target-Like Production of Past Tense with States ${ }^{2}$

\begin{tabular}{|l|l|l|l|r|}
\hline & \multicolumn{2}{|l|}{ JIL } & \multicolumn{2}{l|}{ CIL } \\
\hline Terminated & \multicolumn{2}{|l|}{$(60 \%)$} & 22 & $(85 \%)$ \\
\hline $\begin{array}{l}\text { Possibly Continuing } \\
\text { (Past context) }\end{array}$ & 12 & & 4 & \\
\cline { 1 - 1 } $\begin{array}{l}\text { Continuing } \\
\text { (Past context) }\end{array}$ & 9 & $(40 \%)$ & & $(15 \%)$ \\
\cline { 1 - 2 } Total & 52 & $(100 \%)$ & 26 & $(100 \%)$ \\
\hline
\end{tabular}

While the use of past tense with States in CIL was mostly restricted to terminated States, the use of past tense with States in JIL was more evenly distributed across States that were continuing and States that were terminated. It seems that the Chinese native speakers have made a non target-like association between past tense and situations that have terminated. This association does not appear to be as strong among the Japanese native speakers.

\section{Analysis of L1 Influence:}

The general tendency of using present tense instead of past tense with States is predicted by the Aspect Hypothesis, discussed in section 2.5, and may be a universal tendency rather than a result of $\mathrm{L} 1$ influence

The failure and avoidance of marking States with past tense in CIL could also be explained by the rare occurrence of $l e$ with States in Chinese. As with Habitual Statives, States in Chinese are usually unmarked regardless of temporal location, as they are not inherently bounded spatially or temporally.

The preference in CIL to use past tense with States that have terminated, and present tense with those that are still continuing is likely to be attributable to the transfer of L1 knowledge, namely the influence of the Chinese perfective marker le.

2 Two productions of past tense with States from the JIL sample were excluded from these calculations because of ambiguity. 
.

As discussed in Section 2.6 the function of $l e$ is to view a situation as a complete whole. This is likely to have caused the association in CIL between past tense and situations, including States, that are complete and have reached their final endpoint prior to the moment of speech. This is different from the tense function of English past tense, as past tense with a State in English does not necessarily assert that a State has terminated.

The competence demonstrated in the JIL sample in using past tense with States that are still continuing is also likely to be the result of positive influence from Japanese tense marking. Japanese ta occurs frequently with States to temporally locate them at least partially in the past. As with English past tense, $t a$ does not assert that a State no longer holds at the present. This L1 knowledge seems to have been transferred to the JIL understanding of English past tense.

\subsection{Data and Analysis Conclusion}

The findings presented in this section provide evidence to support the hypothesis of this study. Although some identified Interlanguage tendencies, namely the frequent failure to use past tense with States in JIL, could not be explained by L1 influence, all other tendencies displayed characteristics similar to characteristics of L1 forms.

Chinese perfective le and the lack of tense forms in Chinese appear to have a negative influence on CIL. In CIL, past tense is used to mark perfectivity, even with States. Target English tense forms have a purely tense function with States, asserting only partial temporal location. English tense forms with States are not concerned with whether or not the State has terminated. Chinese perfective le, on the other hand, presents a situation as a whole and is concerned with the completeness and visible end points of a situation. This perfective function of $l e$ appears to have been transferred into the CIL understanding of past tense. This transfer causes States, in particular those that are not terminated, and Habitual Statives in CIL to be left unmarked for past tense in contexts where past tense is obligatory or preferable in target English.

The Japanese $r u$-ta tense distinction appears to have had a positive influence on the JIL understanding of English simple present and past tense. Japanese $r u$ and $t a$, like English simple present and simple past, have purely tense (not aspectual) functions with States. This explains why the purely tense functions of English simple present and simple past with States and Habitual Statives appear to have been grasped by most Japanese participants. In JIL, past tense is accurately used to indicate partial temporal location of States that are still continuing or possibly continuing at Speech Time. Transfer of L1 
knowledge is likely to have facilitated this, as Japanese ta, like English simple past, does not restrict a State to past time.

The identification and analysis of JIL and CIL tendencies in this study has provided evidence that L1 knowledge influences Japanese and Chinese native speakers' understanding of English tense forms in both positive and negative ways.

\section{DISCUSSION}

The approach and methods used in this study were successful in fulfilling the objectives and providing some evidence to support the hypothesis. However, the findings were inconclusive as a result of limitations in the scope and design of the study.

The use of spontaneous oral production data provided natural and reliable samples of JIL and CIL. However, it was somewhat difficult to compare tendencies of JIL and CIL use of tense, with such a limited sample of freely produced data. Though some tendencies were identified, more extensive studies are required to verify these tendencies.

The limited number of participants also created some problems. Since competence in an L2 is subject to individual and circumstantial differences, the Interlanguages of four Japanese and four Chinese native speakers were not enough to represent JIL and CIL in general. In the JIL sample one particular participant (who happened to be the most talkative of the group) displayed tendencies in her tense use that were quite different from the other three participants in the group but were similar to the tendencies found in the CIL sample. Due to the limited number of participants in the group her individual tendencies had a significant impact on the quantitative data. More extensive studies with larger numbers of participants are required to determine whether or not these tendencies are common in the Interlanguages of native Japanese speakers.

Identifying non target-like uses of simple present and simple past in the Interlanguage samples enabled areas of difficulty to be observed. Comparisons of the contexts of non target-like, and target-like uses of the same form enabled the precise nature of the Interlanguage patterns to be identified and analysed. For example, the comparison of the contexts in which Chinese participants accurately produced past tense with States and failed to produce past tense with States, revealed that past tense in CIL was accurately used with States that had terminated prior to Speech Time, but was avoided with States that were continuing at Speech Time. This was verified as a tendency specific to CIL, as past tense was accurately produced in JIL with both States that were continuing at Speech Time and States that had terminated prior to Speech Time. 
.

The application of $\mathrm{L} 1$ and target language comparisons to Interlanguage tendencies was successful in identifying and analysing areas of L1 influence. A number of correlations between Interlanguage tendencies and the characteristics of L1 forms, described in the comparative analysis in section 2.6, were identified. This provided evidence to support the hypothesis that JIL and CIL use of tense and aspect forms are characterised by features of the speakers' respective $\mathrm{L} 1$ forms as a result of $\mathrm{L} 1$ influence.

\section{CONCLUSION}

The integrative approach adopted was effective in fulfilling the three objectives of this thesis. Although this study was limited in scope, the findings provided evidence to support the hypothesis that the use of tense and aspect forms in JIL and CIL are characterised by features of the speakers' respective L1 forms.

Theidentified tendenciesin JIL and CIL were found to have similar characteristics to L1 forms. The findings of this study support the view that L1 knowledge significantly impacts learners' understanding of L2 grammar, and suggest that more research in this area is worthwhile. Such research could have valuable pedagogical implications.

The findings of this study indicate that an understanding of JIL and CIL could potentially assist English teachers in bringing their Japanese and Chinese native speaker students closer to target-like competence in the area of tense. This understanding could also be useful in the development of teaching methods and materials.

Chinese native speakers need to be made aware of the difference between English simple past tense and perfectivity. They need to be explicitly taught that when used with States, past tense does not assert that the State has terminated. They also need to be encouraged to use past tense with Habitual Statives temporally located in the past.

More extensive investigations with larger Interlanguage samples and a greater number of participants are required to confirm and expand on the findings of this study. In the area of English language teaching, further research could build on the findings of this study to develop teaching methods and materials that effectively address difficulties caused by L1 influences in the acquisition of English tense forms. 


\section{References}

Biber, D., Johansson, S., Leech, G., Conrad, S., \& Finegan, E., Grammar of Spoken and Written English (London: Longman, 1999).

Bley-Vroman, R., 'What is the logical problem of foreign language learning?', in Gass, S. M. and Schauchter, J. (eds.), Linguistic Perspectives on Second Language Acquisition (Cambridge: Cambridge University Press, 1989).

Chan, A., 'Syntactic Transfer: Evidence from the Interlanguage of Hong Kong Chinese ESL Learners', Modern Language Journal, 88(1), 2004, pp. 56-73.

Collins, L., 'The Particulars on Universals: A Comparison of the Acquisition of Tense-Aspect Morphology among Japanese- and French-Speaking Learners of English', The Canadian Modern Language Review, 61(2), 2004, pp. 251-274.

Comrie, B., Aspect (Cambridge: Cambridge University Press, 1976).

Comrie, B., Tense (Cambridge: Cambridge University Press, 1985).

Corder, S. P., Error Analysis and Interlanguage (Oxford: Oxford University Press, 1981).

Dietrich, R., Klein, W. and Nayau, C., The Acquisition Temporality in a Second Language (Amsterdam/Philadelphia: John Benjamins Publishing Company, 1995).

Ellis, R., Understanding Second Language Acquisition (Oxford: Oxford University Press, 1985).

Ellis, R. and Barkhuizen, G., Analysing Learner Language (Oxford: Oxford University Press, 2005).

Fries, C., Teaching and Learning English as a Foreign Language (Michigan: University of Michigan Press, 1945).

Horie, K., 'Form-Meaning Interaction in Diachrony: A Case Study From Japanese', English Linguistics, 14, 1997, pp. 428-449.

Hsu, K., A Discourse Analysis of Temporal Markers in Written and Spoken Mandarin Chinese (Lewiston: The Edwin Mellen Press, 1998).

Klien, W., Li, P., \& Hendriks, H., 'Aspect and Assertion in Mandarin Chinese', Natural Language \& Linguistic Theory, 18, 2000, pp. 723-770.

Kokuritsu Kokugo Kenkyuusho (National Institute for Japanese Language), Gendai Nihongo Dōshi no asupekuto to tensu (Tense and Aspect of Modern Japanese Verbs): (Shūei Shuppan, 1985).

Kunihiro, "Tensu to asupekuto: Nihongo / Eigo' (Tense and Aspect: Japanese-English), in Morioka (ed.), Gaikokugo to no Taishō (Meiji Shoin, 1989).

Lado, R., Linguistics Across Cultures (Michigan: University of Michigan Press, 1857).

Leech, G., Meaning and the English Verb (London: Longman, 1971). 
New Voices Volume 2

Li, C. N. and Thompson, S. A., Mandarin Chinese: A Functional Reference Grammar (Berkeley: University of California Press, 1981).

Li, P. and Shirai, Y., The Acquistion of Lexical and Grammatical Aspect (Berlin: Mouton de Gruyter, 2000).

Odlin, T., Language Transfer: Cross-linguistic influence in language learning (Cambridge: Cambridge University Press, 1989).

Ogihara, T., Tense, Attitudes, and Scope (Dordrecht: Kluwer Academic Publishers, 1996).

Ogihara, T., 'Tense and Aspect', in Tsujimura, N. (ed.), The Handbook of Japanese Linguistics (Massachusetts: Blackwell Publishers, 1999).

Olsen, M., A Semantic and Pragmatic Model of Lexical and Grammatical Aspect (New York: Garland Publishing, 1997).

Reichenbach, H., Elements of Symbolic Logic (New York: The Macmillan Company, 1947).

Robison, R., 'The Primacy of Aspect: Aspectual Marking in English Interlanguage', Studies in Second Language Acquisition 12, 1990, pp. 315-330.

Selinker, L., 'Interlanguage', International Review of Applied Linguistics, 10(3), 1972, pp. 209-231.

Shirai, Y. and Kuruno, A., 'The Acquisition of Tense-Aspect Marking in Japanese as a Second Language', Language Learning, 48(2), 1998, pp. 245-279.

Smith, C. S., The Parameter of Aspect (Dordrecht: Kluwer Academic Publishers, 1991).

Soga, M., Tense \& Aspect in Modern Colloquial Japanese (Vancouver: University of British Columbia Press, 1983).

Spolsky, B., 'Contrastive Analysis, Error Analysis, Interlanguage, and Other Useful fads', Modern Language Journal, 63(5/6), 1979, pp. 250-257.

Teramura, H., Nihongo no shintakusu to imi II (Japanese Syntax and Meaning II), (Kuroshio Shuppan, 1982).

Teramura, H., Ronbunshū - Nihongo Bunpō Hen (A collection of essays by Teramura -Japanese Grammar-), (Kuroshio Shuppan, 1993).Vendler, Z., Linguistics in Philosphy (New York: Cornell University Press, 1967).

Waibel, B., 'Corpus-based approaches to learner interlanguage: case studies based on the International Corpus of Learner English', Arbeiten aus Angslistik und Amerikanistik, 30(1-2), 2005, pp. 141-176.

Xiao, R. and McEnery, T., Aspect in Mandarin Chinese (Amsterdam/Philadelphia: John Benjamins Publishing Company, 2004).

Yip, V., Interlanguage and Learnability; From Chinese to English (Amsterdam/Philadelphia: John Benjamins Publishing Company, 1995).

Yoshimoto, K., Tense and Aspect in Japanese and English (Frankfurt am Main: Peter Lang, 1998). 